\title{
Lichenicolous fungi from Far East of Russia
}

\author{
Mikhail P. Zhurbenko \\ Laboratory of the Systematics and Geography of Fungi, Komarov Botanical Institute, Russian Academy of Sciences, \\ Professora Popova str., 2, St. Petersburg, 197376, Russia. \\ E-mail: zhurb58@gmail.com
}

\begin{abstract}
Twenty three species of lichenicolous fungi are newly reported for Jewish Autonomous Region of Russia. Lichenostigma chlaroterae, Nectriopsis physciicola and Sphaerellothecium gallowayi are new to Russia and Asia; Trichonectria rubefaciens is new to Asia; Xenonectriella leptaleae is new to Asian Russia; Lichenostigma cosmopolites and Marchandiomyces corallinus are new to Far Eastern Federal District of Russia. Nectriopsis physciicola is newly documented on Heterodermia, Ovicuculispora parmeliae on Anaptychia, Pyxine and Rinodina, Trichonectria rubefaciens on Myelochroa and Xenonectriella leptaleae on Heterodermia.
\end{abstract}

\section{INTRODUCTION}

So far lichenicolous fungi of the southern part of the Russian Far East have not been specifically inspected. In the period from 9 to 13 August 2013 I made a small survey of these fungi in state nature reserve Bastak located in Jewish Autonomous Region of Russia at its boundary with Khabarovsk Territory. The reserve occupies south-eastern slopes of Bureinskii range covered by coniferous-deciduous forests and northern part of Middle Amur lowland. The survey resulted in a list of 23 species presented below, three of which are new to Russia and four new to Asia.

\section{MATERIAL AND METHODS}

The study is based on 38 specimens examined with Zeiss microscopes Stemi 2000-CS and Axio Imager A1 equipped with Nomarski differential interference contrast optics. Microscopical examination was done in water, $10 \% \mathrm{KOH}(\mathrm{K})$, Lugol's iodine, directly (I) or after a $\mathrm{KOH}$ pretreatment $(\mathrm{K} / \mathrm{I})$ or Brilliant Cresyl blue $(\mathrm{BCr})$. The length, breadth, and length/breadth ratio $(1 / b)$ of asci and ascospores are given (where possible) as: (min-) $\{\mathrm{X}-\mathrm{SD}\}-\{\mathrm{X}+\mathrm{SD}\}(-\max )$, where min and max are the extreme values, $X$ the arithmetic mean, and SD the corresponding standard deviation. The nomenclature of the host lichens follows Skirina (2007). Examined specimens are housed in the mycological herbarium of the V. L. Komarov Botanical Institute in Saint Petersburg (LE).

\section{Collecting sites in state nature reserve Bastak, Jewish Autonomous Region, Far Eastern Federal District of Russia}

1 - $25 \mathrm{~km}$ S of Birobidzhan, Skalistaya Mt. (636 m), 4901'51"N, $132^{\circ} 53^{\prime} 26^{\prime \prime} \mathrm{E}$, alt. 580-630 $\mathrm{m}$, Si-rock outcrops among Pinus-Abiesdominated forest.

$2-30 \mathrm{~km} \mathrm{~S}$ of Birobidzhan, in the vicinities of Paseka Polkovnikova Cabin, 48 59'14"N, $132^{\circ} 53^{\prime} 40^{\prime \prime E}$, alt. $200 \mathrm{~m}$, coniferous-deciduous forest.

3 - near intersection of the road BirobidzhanKukan and Bastak River, 49 01'29' N, $133^{\circ} 01^{\prime} 40^{\prime \prime} \mathrm{E}$, alt. $170 \mathrm{~m}$, open sandpit among coniferous-deciduous forest.

4 - by the road Birobidzhan-Kukan, $49^{\circ} 08^{\prime} 06^{\prime \prime} \mathrm{N}$, $133^{\circ} 08^{\prime} 47^{\prime \prime} \mathrm{E}$, alt. $160 \mathrm{~m}$, open sandpit in coniferous-deciduous forest.

5 - near $39 \mathrm{~km}$ Cabin by the road BirobidzhanKukan, 490 $06^{\prime} 31^{\prime \prime} \mathrm{N}, 133^{\circ} 06^{\prime} 41^{\prime \prime} \mathrm{E}$, alt. 140 $\mathrm{m}$, dwarf shrub bog with sparse Larix trees.

6 - near $39 \mathrm{~km}$ Cabin by the road BirobidzhanKukan, 49 $05^{\prime} 26^{\prime \prime} \mathrm{N}, 133^{\circ} 05^{\prime} 18^{\prime \prime} \mathrm{E}$, alt. 140 m, dwarf shrub bog with sparse Larix trees.

7 - same place, coniferous-deciduous forest.

\section{THE SPECIES}

Abrothallus Bertianus De Not. - 5, on Melanohalea olivacea (apothecia, thallus), 12.08.2013, M. P. Zhurbenko 13128, LE 261193; 6, on M. septentrionalis (thallus), 13.08.2013, M. P. Zhurbenko 13122a, LE 261173a. 
Note - Formerly known in Far Eastern Federal District of Russia from Khabarovsk Territory (Zhurbenko \& Tugi, 2013).

ABrothallus Parmeliarum (Sommerf.) Arnold - 5, on Parmelia squarrosa (thallus), 12.08.2013, M. P. Zhurbenko 13102b, LE 261155b; 6, on P. squarrosa (thallus), 13.08.2013, M. P. Zhurbenko 13101, LE 261165.

Note - Formerly known in Far Eastern Federal District of Russia from Sakha (Yakutiya) Republic, Chukotka Autonomous Region and Kamchatka Territory (Alstrup \& Ahti, 2007; Zhurbenko, 2009a; Zhurbenko et al., 2012).

ABRothallus sp. (Vouauxiomyces anamorph) - 5, on Melanelia septentrionalis (thallus), 12.08.2013, M. P. Zhurbenko 13117, LE 261192.

Note - Examined material is similar to Vouauxiomyces santessonii D. Hawksw. (Hawksworth, 1981), but differs from the latter in having smooth vs. echinulate and somewhat longer conidia (Fig. 1), viz. (6.9-)7.7-12.1(-16.5) $\times$ (4.0-)4.6-5.4(-6.0) $\mu \mathrm{m}(\mathrm{n}=40$, in water) vs. $(7-) 7.5-10.5(-11.5) \times(5-) 5.5-7(-7.5) \mu \mathrm{m}$.

Corticifraga Fuckeli (Rehm) D. Hawksw. \& R. Sant. - 1, on Peltigera sp. (thallus), 9.08.2013, M. P. Zhurbenko 1399, LE 261135.
Note - Formerly known in Far Eastern Federal District of Russia from Sakha (Yakutiya) Republic, Kamchatka Territory and Sakhalin Region (Zhurbenko et al., 2005, 2012; Zhurbenko, 2009b; Zhurbenko \& Vershinina, 2014).

DACTYLOSPORA cf. GLAUCOMARIOIDES (Tuck.) Hafellner - 1, on Ochrolechia akagiensis (thallus, occasionally apothecia) growing on mosses over shaded rocks, 9.08.2013, M. P. Zhurbenko 13107, LE 261065.

Notes - Apothecia sessile, with medium olive brown, paraplectenchymatous stipe ca. 70-250 $\times$ 60-150 $\mu \mathrm{m}$ (Fig. 2), rounded to angular compressed or lobed in surface view, disc plane to slightly convex, black, epruinose, matt, 100-450 $\mu \mathrm{m}$ diam., usually surrounded by elevated, often slightly cracked margin 40-60 $\mu \mathrm{m}$ wide, dispersed to occasionally confluent/concrescent by a few. Hymenium permanently I+ blue, K/I+ blue with red patches. Ascospores with (1-)3(-6) transsepta and often 1-2 oblique or longisepta in central segments. Pathogenicity not observed. Examined material differs from the species descriptions in Hafellner (1979) and Joshi et al. (2010) in having: 1) stipitate ascomata; 2) amyloid hymenium (not hemiamyloid, i.e. I+ blue turning red); 3) somewhat smaller ascospores, viz. (8.4-) 10.4-13.6(-16.5) × (4.0-)4.4-5.4(-6.4) $\mu \mathrm{m}, 1 / \mathrm{b}=(1.6-) 2.1-2.9(-3.8)(\mathrm{n}=116$, in wa-

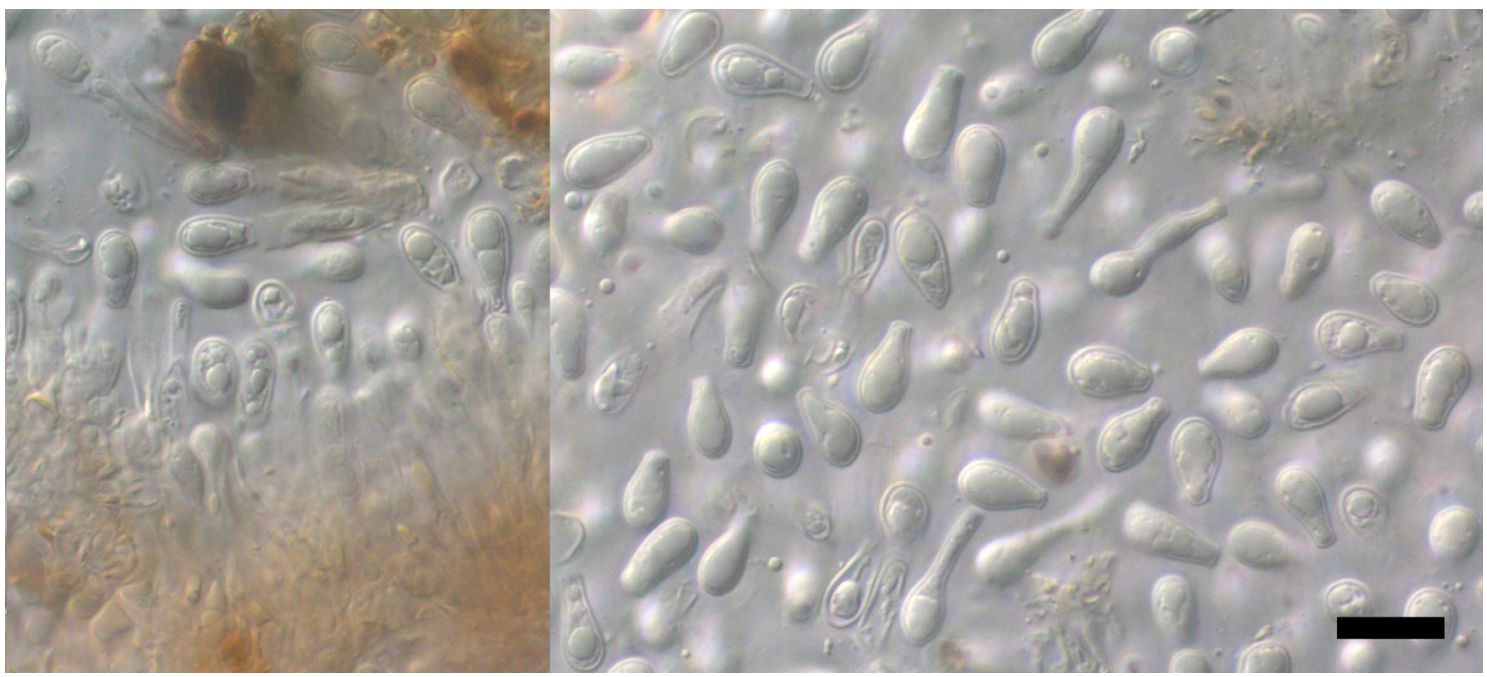

Fig. 1. Abrothallus sp. (Vouauxiomyces anamorph) on Melanelia septentrionalis (LE 261192). Conidiogenous cells (left) and conidia (right) (in water). Bar $=10 \mu \mathrm{m}$. 


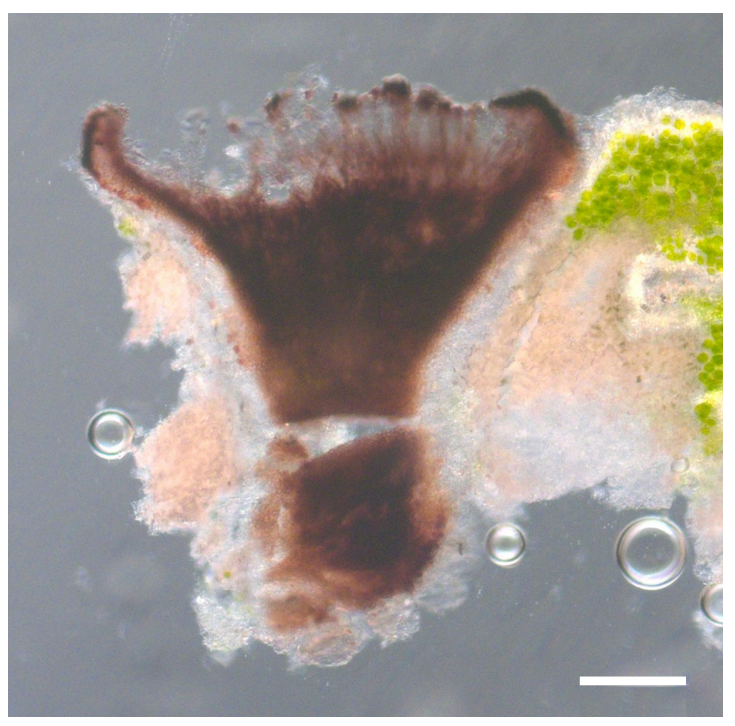

Fig. 2. Dactylospora cf. glaucomarioides (LE 261065). Stipitate ascomata in cross section (in water). Bar $=100 \mu \mathrm{m}$.

ter, I or K/I) vs. $12.5-19 \times 5.5-7.5 \mu \mathrm{m}$ (Joshi et al., 2010) or 12.5-19 × 5-7.5 $\mu \mathrm{m}$ (Hafellner, 1979). The species was formerly reported in Far Eastern Federal District of Russia from Sakha (Yakutiya) Republic (Zhurbenko, 2009a).

Homostegia Piggotil (Berk. \& Broome) P. Karst. 1, on Parmelia shinanoana (thallus), 9.08.2013, M. P. Zhurbenko 13104, LE 261175.

Notes - Formerly known in Far Eastern Federal District of Russia from Sakha (Yakutiya) Republic (Zhurbenko et al., 2005). Parmelia shinanoana is a new host species.

InTRALiChen ChRistiansenil (D. Hawksw.) D. Hawksw. \& M.S. Cole - 5, on Nesolechia oxyspora (hymenium of apothecia) growing on Parmelia squarrosa, 12.08.2013, M. P. Zhurbenko 13102c, LE 261155c.

Note - Formerly known in Far Eastern Federal District of Russia from Sakha (Yakutiya) Republic and Chukotka Autonomous Region (Zhurbenko, 2009a).

Lichenoconium Pyxidatae (Oudem.) Petr. \& Syd. 7, on Cladonia ochrochlora (podetia), 13.08.2013, M. P. Zhurbenko 13125, LE 261105.
Note - Formerly known in Far Eastern Federal District of Russia from Sakha (Yakutiya) Republic and Chukotka Autonomous Region (Zhurbenko \& Alstrup, 2004).

Lichenoconium usneae (Anzi) D. Hawksw. - 5, on Melanohalea olivacea (disc of apothecia), 12.08.2013, M. P. Zhurbenko 13116, LE 260902; 6, on M. olivacea (disc of apothecia), 13.08.2013, M. P. Zhurbenko 13115, LE 261163; 6, on M. septentrionalis (thallus), 13.08.2013, M. P. Zhurbenko 13122b, LE 261173b.

Note - Formerly known in Far Eastern Federal District of Russia from Sakha (Yakutiya) Republic, Chukotka Autonomous Region and Kamchatka Territory (Zhurbenko, 2009a; Zhurbenko et al., 2012; Zhurbenko \& Vershinina, 2014).

Lichenostigma alpinum (R. Sant., Alstrup \& D. Hawksw.) Ertz \& Diederich - 1, on Ochrolechia akagiensis (thallus), 9.08.2013, M. P. Zhurbenko 13108, LE 261185.

Note - Ochrolechia akagiensis is a new host species.

LiChENOSTIGMA CHLAROTERAE (F. Berger \& Brackel) Ertz \& Diederich - 2, on Lecanora symmicta (apothecia, thallus), 10.08.2013, M. P. Zhurbenko 13121, LE 260985.

Notes - Formerly known from Europe (Austria, Germany and Portugal) (Berger \& Brackel, 2011). New to Russia and Asia.

Lichenostigma cosmopolites Hafellner \& Calat. - 1, on Xanthoparmelia stenophylla (thallus), 9.08.2013, M. P. Zhurbenko 13113, LE 260942.

Notes - Formerly known in Russia from Karelia Republic and Zabaikal'e Territory of Russia (A1strup et al., 2005; Zhurbenko \& Yakovchenko, 2014). New to Far Eastern Federal District of Russia.

LiCHENOSTIGMA MAURERI Hafellner - 5, on Evernia mesomorpha (thallus), 12.08.2013, M. P. Zhurbenko 13114, LE 261063; 6, on E. mesomorpha (thallus), 13.08.2013, M. P. Zhurbenko 13120, LE 260995.

Note - Formerly known in Far Eastern Federal District of Russia from Sakha (Yakutiya) Republic, Chukotka Autonomous Region, Magadan Region, Kamchatka Territory, Khabarovsk Terri- 
tory and Primor'e Territory (Zhurbenko, 2009b; Zhurbenko et al., 2012; Zhurbenko \& Tugi, 2013; Zhurbenko \& Zhdanov, 2013).

Marchandiomyces corallinus (Roberge) Diederich \& D. Hawksw. - 3, on Melanohalea cf. olivacea (thallus), 12.08.2013, M. P. Zhurbenko 13129, LE 261073; 5, 12.08.2013, on Hypogymnia physodes (thallus), M. P. Zhurbenko 13130a, LE 261095a; on Tuckermannopsis ciliaris (thallus) and partly on adjacent phorophyte (Larix) bark with remnants of lichens thalli, M. P. Zhurbenko 13130b, LE 261095b.

Note - New to Far Eastern Federal District of Russia.

NeCTRIOPSIS Physcilcola D. Hawksw. \& Earl.Benn. - 7, on Heterodermia sp. (bleached lobes, occasionally rhizines, soralia and adjacent mosses with lichen soredia), 13.08.2013, M. P. Zhurbenko 13110, LE 261005.

Notes - Examined specimen fits in most features the original description (Earland-Bennett et al., 2006), except of the colour of the ascomata and the size of the ascospores. The ascomata are not pinkish but pale orange to clay-buff (Fig. $3)$. The ascospores are on an average somewhat longer than in the original description, (16.7-) 18.4-21.4(-22.9) × (5.4-)5.9-6.7(-7.0) $\mu \mathrm{m}$, $1 / \mathrm{b}=(2.7-) 2.9-3.5(-4.0)(\mathrm{n}=46$, in water) vs. (14-)14.5-18(-22.5) × 5.5-8 $\mu \mathrm{m}$. So far the species was known from several collections in Spain

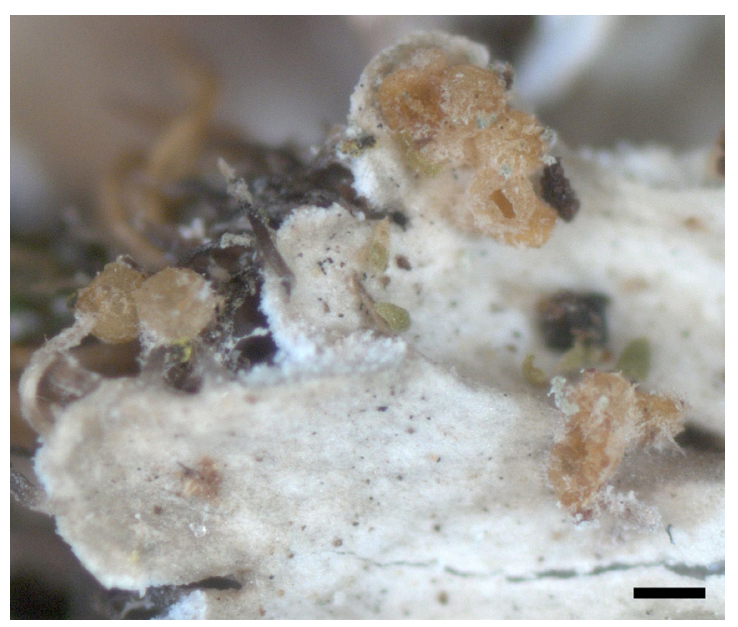

Fig. 3. Nectriopsis physciicola (LE 261005). Ascomata habitus. Bar $=200 \mu \mathrm{m}$. (type) and Italy on Physcia stellaris (type) and $P$. biziana (Earland-Bennett et al., 2006; Brackel, 2011). New to Russia and Asia. Heterodermia is a new host genus.

Neolamya peltigerae (Mont.) Theiss. \& Syd. - 7 , on Peltigera collina (thallus), 13.08.2013, M. P. Zhurbenko 13100, LE 261075.

Note - Formerly known in Far Eastern Federal District of Russia from Sakha (Yakutiya) Republic, Chukotka Autonomous Region and Khabarovsk Territory (Alstrup \& Ahti, 2007; Zhurbenko, 2009b).

Nesolechia oxyspora (Tul.) A. Massal. - 1, on Punctelia sp. (thallus), 9.08.2013, M. P. Zhurbenko 13103, LE 261195; 2, on Myelochroa aurulenta (thallus), 10.08.2013, M. P. Zhurbenko 13123, LE 261152; 5, on Parmelia squarrosa (thallus), 12.08.2013, M. P. Zhurbenko 13102a, LE 261155a.

Note - Formerly known in Far Eastern Federal District of Russia from Sakha (Yakutiya) Republic, Chukotka Autonomous Region and Kamchatka Territory (Zhurbenko, 2009a; Zhurbenko et al., 2012). Myelochroa aurulenta and Parmelia squarrosa are new host species.

OvicuCUlisPora PARMELIAE (Berk. \& Curt.) Etayo - 1, on Cladonia spp. (podetia and both sides of basal squamules) and adjacent Parmelia sp. (thallus), 9.08.2013, M. P. Zhurbenko 13132, LE 261025; 1, on Heterodermia cf. obscurata (both sides of lobes and rhizines), 9.08.2013, M. P. Zhurbenko 13133, LE 261143; 1, on Myelochroa entotheiochroa (thallus) and adjacent green mosses, 9.08.2013, M. P. Zhurbenko 13105, LE 261145; 1, on Rinodina xanthophaea (thallus), 9.08.2013, M. P. Zhurbenko 13134, LE 261093; 1, on neighbouring Anaptychia sp. (thallus) and Heterodermia cf. microphylla (thallus), 9.08.2013, M. P. Zhurbenko 13135, LE 261153; 1, on Pyxine sorediata (thallus), 9.08.2013, M. P. Zhurbenko 13111, LE 261055.

Notes - All collections are from the same site, where the species was rather common and abundant on various hosts growing on forested mossy rocks. Heavy infections cause slight bleaching of host lobes. Ascomata 150-400 $\mu \mathrm{m}$ diam., subglobose, pale to medium cream or pink orange, usually with conspicuous naked 
and thus more brightly coloured small papilla, discrete to often concrescent by up to 6 , sometimes associated with a subiculum. Exciple pale yellow-orange, K-. Asci usually with 4 microspores and one macrospore, sometimes with just 4 or 5 microspores. Ascospores can be roughly subdivided to microspores and macrospores, though many spores of intermediate size were also observed. Microascospores mostly ellipsoid, with small and large guttules, wall finely verruculose (hardly visible even at DIC), 1-septate or very rarely aseptate, not or slightly constricted at the septum, (6.8-)8.7-11.7(-16.5) $\times$ (3.3-)4.5-5.5(-7.0) $\mu \mathrm{m}, 1 / \mathrm{b}=(1.4-) 1.7-2.5(-3.6)$ ( $\mathrm{n}=143$, in water). Macroascospores ellipsoid to occasionally obovoid, ends rounded or very rarely acute, usually strongly constricted at the septum, 1 - or very rarely 2 -septate, sometimes heteropolar, easily broken down into individual cells, wall ca. $1.5 \mu \mathrm{m}$ thick, smooth, usually with small guttules, (18.4-)42.4-73.0(-86.0) $\times(6.8-) 18.3-33.3(-40.0) \mu \mathrm{m}, 1 / \mathrm{b}=(1.9-) 2.2-$ $2.6(-2.9)$ ( $n=311$, in water). The sizes of the macroascospores strongly vary both in different perithecia and specimens, which agrees with the former observations on the species (Hawksworth \& Booth, 1976; Etayo, 2010). For instance, in LE 261025 (on Cladonia) macroascospores are comparatively small, (18.4-)20.6-28.6(-32.0) $\times$ (6.8-)9.0-13.0(-14.2) $\mu \mathrm{m}, 1 / \mathrm{b}=(1.7-) 2.0-2.6(-$ 2.8) ( $\mathrm{n}=20$, in water). On the whole examined macroascospores are larger than reported for the species by Hawksworth \& Booth (1976) [34-50 $(-60) \times 12-18(-20) \mu \mathrm{m}]$ or Etayo $(2010)$ (38-65 × 16-23 $\mu \mathrm{m}, 55-78 \times 22-26 \mu \mathrm{m}, 33-50$ $\times 12-23 \mu \mathrm{m}$ in different specimens) and constitute a transition to those of Ovicuculispora macrospora Etayo characterized by somewhat larger ascomata (300-500 $\mu \mathrm{m}$ diam.) and larger macroascospores (67-105 × 32-40 $\mu \mathrm{m})$ (Etayo, 2010). However, the latter species is yet known only by the holotype from Peru, so its range of variation is obscure. Ovicuculispora parmeliae was formerly known in Russia from Primor'e Territory (Etayo, 2010). Anaptychia, Pyxine and Rinodina are new host genera.

Pyrenidium actinellum Nyl. - 4, on Baeomyces rufus (thallus), 12.08.2013, M. P. Zhurbenko 13119, LE 261105.

Note - Formerly known in Far Eastern Federal District of Russia from Sakha (Yakutiya)
Republic and Chukotka Autonomous Region (Zhurbenko, 2008, 2009a, b).

SphaEREllothecium Gallowayi Diederich -1 , on Heterodermia sp. (thallus), 9.08.2013, M. P. Zhurbenko 13112, LE 261083.

Notes - Examined material agrees in all aspects with the species protologue (Diederich, 2007). Additionally we observed that the ascospores are occasionally pale brown, and the ascus wall is $\mathrm{BCr}-$. So far the species was known from Australia and Papua New Guinea (Diederich, 2007). New to Russia and Asia.

Tremella Cetraritcola Diederich \& Coppins - 5, on Tuckermannopsis ciliaris (thallus), 12.08.2013, M. P. Zhurbenko 13124, LE 261113.

Note - Formerly known in Far Eastern Federal District of Russia from Kamchatka Territory (Zhurbenko et al., 2012).

Trichonectria RUbefaciens (Ellis \& Everh.) Diederich \& Schroers - 1, on Myelochroa subaurulenta (thallus), 9.08.2013, M. P. Zhurbenko 13132, LE 260922.

Notes - Formerly known in Russia from Leningrad Region (Kuznetsova et al., 2012). New to Asia. Myelochroa is a new host genus.

Xenonectriella leptaleae (J. Steiner) Rossman \& Lowen - 2, on Heterodermia sp. (lobes), 10.08.2013, M. P. Zhurbenko 13131, LE 261123; 7, on Heterodermia sp. (lobes), 13.08.2013, M. P. Zhurbenko 13109, LE 261085.

Notes - Acomata red or occasionally orange, subglobose to pyriform, papillate, up to 250 $\mu \mathrm{m}$ diam., protruding only in ostiolar area, dispersed to aggregated. Interascal filaments have not been mentioned for this genus in Rossman et al. (1999), however, in the examined specimens they are well-developed, 2-3.5 $\mu \mathrm{m}$ wide, branched. Exciple orange, $\mathrm{K}+$ purple, yellow in lactic acid. Ascospores broadly ellipsoid, (9.3-) 10.1-11.9(-13.9) × (6.0-)7.0-8.0(-8.6) $\mu \mathrm{m}$, $1 / \mathrm{b}=(1.2-) 1.3-1.7(-2.0)(\mathrm{n}=88$, in water or $\mathrm{K})$, at first hyaline and smooth-walled, then medium orange or yellow-brown and prominently tuberculate, 1-septate or very rarely aseptate, more or less constricted at the septum, mostly with one large guttule in each cell, uniseriate 
in an ascus. Infected host lobes are strongly bleached. Examined material well fits description of the species in Rossman et al (1999), except "K+ pale brown to black" reaction of the exciple reported by the authors. Formerly known in Russia from Pskov Region, Leningrad Region and Komi Republic (Zhurbenko, 2007; Popov et al., 2008; Stepanchikova et al., 2011). New to Asian Russia. Heterodermia is a new host genus.

\section{ACKNOWLEDGEMENTS}

I am grateful to the director of Bastak Reserve Alexander Yu. Kalinin, as well as to Ivan Polkovnikov, Pavel Zban' and Ekaterina Lonkina for the help and hospitality during my work in the reserve. Irina F. Skirina and Dmitrii E. Himelbrant are thanked for the help in identification of the host lichens. Ave Suja, Wolfgang von Brackel, Javier Etayo and Kerry Knudsen provided valuable discussion on critical specimens.

\section{REFERENCES}

Alstrup, V. \& Ahti, T. 2007. New reports of lichenicolous fungi, mainly from Finland and Russia. Karstenia 47: 1-4.

Alstrup, V., Zavarzin, A. A., Kocourcova, J., Kravchenko, A. V., Fadeeva, M. A. \& Shiefelbein, U. 2005. Lichens and lichenicolous fungi found in Northern Ladoga area (Republic of Karelia) during the international fieldtrip in August 2004, prior to the fifth congress of International Lichenological Association. Trudy Karelskogo nauchnogo tsentra RAN (Petrozavodsk) 5: 3-15.

Berger, F. \& Brackel, W. v. 2011. Eine weitere Art von Phaeosporobolus auf Lecanora chlarotera. Herzogia 24: 351-356. http://dx.doi.org/10.13158/ heia.24.2.2011.351

Brackel, W. v. 2011. Lichenicolous fungi and lichens from Puglia and Basilicata (southern Italy). Herzogia 24: 65 -101. http://dx.doi.org/10.13158/ heia.24.1.2011.65

Diederich, P. 2007. Sphaerellothecium gallowayi sp. nov., a new lichenicolous ascomycete on Heterodermia from Australia and Papua New Guinea. Bibliotheca Lichenologica 95: 165-169.

Earland-Bennett, P. M., Hitch, C. J. B. \& Hawksworth, D. L. 2006. New records and new species of lichens and lichenicolous fungi from Mataelpino (Sierra de Guadarrama, Comunidad de Madrid). Boletín de la Sociedad Micológica de Madrid 30: 243-248.

Etayo, J. 2010. Hongos liquenícolas de Perú Homenaje a Rolf Santesson. Bulletin de la Société linnéenne de Provence 61: 1-46.
Hawksworth, D. L. 1981. The lichenicolous coelomycetes. Bulletin of the British Museum (Natural History), Botany Series 9: 1-98.

Hawksworth, D. L. \& Booth, C. 1976. Some observations on Nectria heterospora. Mycologia 68: 195-200. http: / / dx.doi.org/ 10.2307/3758914

Joshi, Y., Knudsen, K., Wang, X. Y. \& Hur, J.-S. 2010. Dactylospora glaucomarioides (Ascomycetes, Dactylosporaceae): a lichenicolous fungus new to South Korea. Mycobiology 38: 321-322. http:// dx.doi.org/ 10.4489/MYCO.2010.38.4.321

Kuznetsova, E. S., Motiejūnaitè, J., Stepanchikova, I. S., Himelbrant, D. E. \& Czarnota, P. 2012. New records of lichens and allied fungi from the Leningrad Region, Russia. III. Folia Cryptogamica Estonica 49: 31-37.

Popov, E. S., Shabunin, D. A. \& Mel'nik, V. A. 2008. Contributions to the studies of mycobiota in Novgorod and Pskov regions. III. Pyrenocarpous ascomycetes. Mikologiya i fitopatologiya 42(2): 137-151. (in Russian).

Rossman, A. Y., Samuels, G. J., Rogerson, C. T. \& Lowen, R. 1999. Genera of Bionectriaceae, Hypocreaceae and Nectriaceae (Hypocreales, Ascomycetes). Studies in Mycology 42: 1-248.

Skirina, I. F. 2007. Lichens. In: Flora, mycobiota and vegetation of Bastak reserve. Dal'nauka, Vladivostok. pp. 209-260 (in Russian).

Stepanchikova, I. S., Schiefelbein, U., Alexeeva, N. M., Ahti, T., Kukwa, M., Himelbrant, D. E. \& Pykälä, J. 2011. Additions to the lichen biota of Berezovye Islands, Leningrad Region, Russia. Folia Cryptogamica Estonica 48: 95-106.

Zhurbenko, M. P. 2007. The lichenicolous fungi of Russia: geographical overview and a first checklist. Mycologia Balcanica 4: 105-124.

Zhurbenko, M. P. 2008. Lichenicolous fungi from Russia, mainly from its Arctic. II. Mycologia Balcanica 5: 13-22.

Zhurbenko, M. P. 2009a. Lichenicolous fungi and some lichens from the Holarctic. Opuscula Philolichenum 6: 87-120.

Zhurbenko, M. P. 2009b. Lichenicolous fungi and lichens from the Holarctic. Part II. Opuscula Philolichenum 7: 121-186.

Zhurbenko, M. P. \& Alstrup, V. 2004. Lichenicolous fungi on Cladonia mainly from the Arctic. Acta Universitatis Upsaliensis, Symbolae Botanicae Upsaliensis 34: 477-499.

Zhurbenko, M. P., Himelbrant, D. E., Kuznetsova, E. S. \& Stepanchikova, I. S. 2012. Lichenicolous fungi from the Kamchatka Peninsula, Russia. The Bryologist 115: 295-312. http://dx.doi. org/10.1639/0007-2745-115.2.295

Zhurbenko, M. P., Raynolds, M. K., Walker, D. A. \& Matveeva, N. V. 2005. Lichens and lichenicolous fungi from the Kolyma delta region, Russian Arctic. Graphis Scripta 17: 27-31. 
Zhurbenko, M. P. \& Tugi, E. W. 2013. Some noteworthy lichenicolous fungi from Khabarovsk Territory of Russia. Mycosphere 4(1): 46-51.

Zhurbenko, M. P. \& Vershinina, S. E. 2014. Opegrapha bryoriae sp. nov. and other lichenicolous fungi from Asian Russia. Herzogia 27: 93-109.

Zhurbenko, M. P. \& Yakovchenko, L. S. 2014 A new species, Sagediopsis vasilyevae, and other lichenicolous fungi from Zabaikal'skii Territory of
Russia, southern Siberia. Folia Cryptogamica Estonica 51:121-130. http://dx.doi.org/10.12697/ fce.2014.51.14

Zhurbenko, M. P. \& Zhdanov, I. S. 2013. Melaspilea galligena sp. nov. and some other lichenicolous fungi from Russia. Folia Cryptogamica Estonica 50: 89-99. http://dx.doi.org/10.12697/ fce.2013.50.12 
120 Folia Cryptog. Estonica 